ISSN 1392-3196 / e-ISSN 2335-8947

Zemdirbyste-Agriculture, vol. 104, No. 3 (2017), p. 229-234

DOI 10.13080/z-a.2017.104.029

\title{
Quality and developmental changes in white head cabbage (Brassica oleracea L.) and radish (Raphanus sativus L.) during winter storage
}

\author{
Alina VIŠKELIENĖ $^{1}$, Giedrè SAMUOLIENE ${ }^{1,2}$, Rasa KARKLELIENË ${ }^{1}$, Pranas VIŠKELIS ${ }^{1}$, \\ Audrius SASNAUSKAS ${ }^{1}$, Pavelas DUCHOVSKIS ${ }^{1,2}$ \\ ${ }^{1}$ Institute of Horticulture, Lithuanian Research Centre for Agriculture and Forestry \\ Kauno 30, Babtai, Kaunas distr., Lithuania \\ E-mail: g.samuoliene@1sdi.lt
}

${ }^{2}$ Aleksandras Stulginskis University

Studentų 11, Akademija, Kaunas distr., Lithuania

\begin{abstract}
The aim of this study was to investigate the changes of quality indices and to evaluate the action of phytohormones and soluble sugars in developmental processes of Brassicaceae plants: white head cabbage (Brassica oleracea L., 'Rocktor H') and winter type radish (Raphanus sativus L., 'Murzynka') during winter storage. Radish and white head cabbage were harvested on the $19^{\text {th }}$ of September and $14^{\text {th }}$ of October, respectively.

The switching from juvenile period (II organogenesis stage) to reproductive (III organogenesis stage) development started in November for white head cabbage and in January for radish, winter type, and conditioned the beginning of evocation processes. The mitotic activity of apical meristems started, and the development of floral meristems was observed only in spring - IV organogenesis stage was identified. Thus, this means that processes of II evocation stage can occur during storage, at low temperature conditions and in the dark for both plants. The increasing pattern of reducing sugars, sucrose, total sugars and soluble solids could be due to slower rate of hydrolysis of carbohydrates, which has implication for better quality maintenance. On the other hand, significant decline of hexoses (about 1.5 and 4.7 times in white head cabbage and radish, respectively) and sucrose (about 2.0 and 19.0 times in white head cabbage and radish, respectively), probably due to sugar cleavage, in storage organs of both harvested vegetables was observed during storage. The increasing pattern of hexoses, especially glucose ( 2.2 times in both plants), sucrose (7.5 times in white head cabbage), gibberellin (1.3 and 2.2 times in white head cabbage and radish, respectively) and indole- 3 -acetic acid ( 0.8 times in white head cabbage) during evocation (III and IV organogenesis stages) was observed in apical meristems of both plants. Thus many developmental processes, including cell division within the apical meristems and flowering, appear to depend on sugar-hormone signalling pathway.
\end{abstract}

Key words: evocation, flowering initiation, phytohormones, sugars, winter storage.

\section{Introduction}

Postharvest physiology allows evaluation of living plant tissues after they have denied further nutrition by picking (El-Ramady et al., 2015). The quality of vegetables depends on harvesting time, which is determined by maturity stage. Therefore it is important to take into account physiological maturity, when crop is capable of further development when it is harvested, and horticultural maturity refers to the stage of development at which the crop is ready for use by consumers (Dhatt, Mahajan, 2007). Most vegetables are leaves (cabbage), petioles, or stems containing chlorophyll, or roots (radish), tubers, or fruits that predominantly contain storage components such as starch (Paliyath et al., 2008). Underground storage organs usually accumulate carbon in the form of starch and sugars, both of which are important quality parameters (El-Ramady et al., 2015). Further, at low temperatures the storage starch is converted to sugars. The essential roles of sugars as sources of carbon skeleton for the complex biochemical metabolism in plants contribute to the postharvest life of vegetables (Nishikawa et al., 2005; Suthumchai et al., 2007); moreover, sucrose and hexoses also act as long-distance signalling molecules (León, Sheen, 2003; Eveland, Jackson, 2011). The principal causes

Please use the following format when citing the article:

Viškelienė A., Samuolienė G., Karklelienė R., Viškelis P., Sasnauskas A., Duchovskis P. 2017. Quality and developmental changes in white head cabbage (Brassica oleracea L.) and radish (Raphanus sativus L.) during winter storage. Zemdirbyste-Agriculture, 104 (3): 229-234 DOI 10.13080/z-a.2017.104.029 
of postharvest losses in cabbage generally occur due to relatively high respiration rates during storage (Kitinoja, Kader, 2002). Plant nutrition is also an important factor affecting susceptibility to postharvest stress. Sams and Conway (2003) stated that relatively high pre-harvest nitrogen is often associated with poor postharvest quality of many fruits and vegetables. Thus, physiological aspects and the understanding of the molecular processes that occur during postharvest and storage would enhance shelf life and preservation of quality of horticultural produce.

Other aspect of the manuscript is developmental changes in Brassicaceae plants during storage. The floral transition is a critical developmental change in plant life cycle. The general body plan of plants is established during embryogenesis, when the undifferentiated meristematic regions of root and shoot are set aside. However, much of plant development occurs post embryonically, through the reiterative production of organ primordia at the shoot apical meristem. In most species, the apical meristems initially give rise to vegetative organs such as leaves, but at some point, the apical meristems make the transition to reproductive development and the production of flowers (Davière et al., 2008; Tognetti et al., 2013). Plants undergo the floral transition only during certain seasons of the year through multiple regulatory networks that interpret environmental signals, such as day lengths and temperature fluctuations (Kim, Sung, 2014). The requirement for vernalization serves in part to prevent flowering in the fall season prior to winter, but permits flowering in the following spring. The developmental processes of apical meristems are determined by changes and interaction of signalling molecules, such as phytohormones and soluble sugars (León, Sheen, 2003). Both sucrose and glucose are included in sugar sensing, although they play different roles in plant function, as glucose is associated with organ growth, while sucrose is more associated with the maturity and full functionality of plant organs (Tognetti et al., 2013). Sugar and hormone connections and participation in floral initiation are well analyzed in herbaceous species (Eveland, Jackson, 2011; León, Sheen, 2003; Samuolienè et al., 2015), horticultural trees (Wilkie et al., 2008; Samuolienè et al., 2016), but little is known what is happening in apical meristems of vegetables grown for seeds during storage. Moreover, in horticulture, there is little research data on cabbage and radish morphogenetic mechanisms and their control processes. Therefore, in order to optimize the performance, it is necessary to investigate the formation of inflorescence axis elements at various stages of organogenesis.

The aim of this study was to investigate the changes of quality indices and to evaluate the action of phytohormones and soluble sugars in developmental processes of Brassicaceae plants, white head cabbage and radish grown for seeds, during winter storage.

\section{Materials and methods}

A field experiment was carried out in 2013-2015 in Institute of Horticulture, Lithuanian Research Centre for Agriculture and Forestry. The soil type - sandy loam (Calc(ar)i-Epihypogleyc Luvisol, LVg-p-w-cc). White head cabbage (Brassica oleracea L., 'Rocktor' H) was harvested on the $14^{\text {th }}$ of October, after winter storage planted on the $25^{\text {th }}$ of April. Winter type radish (Raphanus sativus L., 'Murzynka') was harvested on the $19^{\text {th }}$ of September, after winter storage planted on the $20^{\text {th }}$ of May. Radish was cultivated according to conventional growing technology: soil was fertilized with Cropcare (NPK 11$\left.11-21 / 3.0 \mathrm{~kg} \mathrm{a}^{-1}\right)$ before planting, ammonium nitrate (1.0 $\left.\mathrm{kg} \mathrm{a}^{-1}\right)$ and Powhumus $\left(0.1 \mathrm{~kg} \mathrm{a}^{-1}\right)$ were applied once per treatment. White head cabbage was cultivated according to organic growing technology: Ecolplant $\left(3.0 \mathrm{~kg} \mathrm{a}^{-1}\right)$ and potassium magnesia $\left(2.0 \mathrm{~kg} \mathrm{a}^{-1}\right)$ were applied in spring before planting; plants were sprayed with Biocat $15(0.31$ $\mathrm{kg} \mathrm{a}^{-1}$ ) during vegetation. All plants were sprayed with NeemAzal-T/S $0.5 \%$ solution. Vegetables were stored at $1-4^{\circ} \mathrm{C}, 90 \%$ humidity during winter storage in the dark.

The chemical composition and physiological indices were evaluated in different developmental stages of vegetables during winter storage till planting in the field: organogenesis stage (Куперман и др., 1982) and flowering initiation stage (Duchovskis, 2000). Soluble solids were determined by refractometric method digital refractometer ATAGO PR-32 (Japan), sugars - according to AOAC (1990) method. The amount of nitrates was measured potentiometrically with an ionselective electrode (Geniatakis et al., 2003).

Phytohormones were analyzed in axillary buds, stem or root-crop, using chromatograph Shimadzu UHPLC (Japan) with ultra-high-speed LC/MS, according to the method, proposed by Vitti et al. (2013). Separation of phytohormones gibberellin $\left(\mathrm{GA}_{3}\right)$ and indole-3-acetic acid (IAA) was performed on column YMC-UltraHT Pro C18 (Japan), $3.0 \times 75 \mathrm{~mm}$. Mobile phase - double distilled water $(0.5 \%$ formic acid $)$ - methanol (90:10, $\mathrm{v} / \mathrm{v})$ in positive mode and double distilled water $(0.5 \%$ formic acid $)$ - methanol $(80: 20, \mathrm{v} / \mathrm{v})$ in negative mode, flow rate $-0.2 \mathrm{ml} \mathrm{min}^{-1}$.

Fructose, glucose and sucrose were analysed in apical meristem, stem and root-crop. About $1 \mathrm{~g}$ of fresh plant tissue was ground and diluted with $+70^{\circ} \mathrm{C}$ $4 \mathrm{ml}$ double distilled water. The extraction was carried out for $24 \mathrm{~h}$. The samples were filtered using cellulose acetate (pore diameter $0.22 \mu \mathrm{m}$ ) syringe filters. The analyses were performed on chromatograph Shimadzu HPLC (Japan) with a low temperature evaporative light scattering detector (ELSD-LTII); oven temperature was maintained at $+40^{\circ} \mathrm{C}$. Separation of carbohydrates was performed on carbohydrate column $(250 \times 4 \mathrm{~mm})$ EC 250/4 NUCLEOSIL (Germany), mobile phase acetonitrile - water $(79: 21, \mathrm{v} / \mathrm{v})$, flow rate $-2 \mathrm{ml} \mathrm{min}^{-1}$.

The data was analysed using a one-way analysis of variance $(A N O V A)$, with Fisher's LSD test at the confidence level $p=0.05$. Data was processed using software STATISTICA 10.

\section{Results and discussion}

Biennial plants produce vegetative structures in one season and induce flowering in the flowering season only after they are exposed to prolonged winter or cold treatment. White head cabbage and radish (winter type) are biennial plants; therefore inflorescences are formed in the second year. Data showed (Table 1), that juvenile period of white head cabbage ended in November, while for radish it ended at the end of January. Harvested mature plants have a lot of nutrients stored in storage organs, therefore in November and January white head cabbage 
Table 1. Development of white head cabbage and radish during storage

\begin{tabular}{ccc}
\hline $\begin{array}{c}\text { Organogenesis stages, } \\
\text { flowering initiation stages }\end{array}$ & White head cabbage & Radish \\
\hline II - juvenile period & October 14 - November 7 & September 17 - January 27 \\
III, I - evocation stage & November 7 - March 18 & January 28 - May 17 \\
IV, II - evocation stage & March 19- May 07 & May 18 - May 31 \\
V - flower initiation and differentiation stage & May 08 - May 18 & June 1-7 \\
VI-VII - initiation of gametes & May 19- June 15 & June 8-14 \\
\hline
\end{tabular}

$\mathrm{n}=25$ plants during particular development stage

and radish respectively, reached III organogenesis stage, starting the processes of I evocation stage. The mitotic activity of apical meristems started, the development of floral meristems was observed only in spring, IV organogenesis stage was identified. This means that processes of II evocation stage can occur during storage, at low temperature conditions and in the dark and only after that the plants were planted in the field.

Sugar loss during vegetable storage by using a respiratory model was explained by Singh and Verma (2012). The initial decrease in reducing sugars and soluble solids during storage was considered to have occurred due to carbohydrate consumption during respiration (Lepse et al., 2014). Biesiada et al. (2009) showed that storage duration conditioned the decrease of soluble solids, reducing and total sugars in pumpkin. However, contrary results were obtained by Mohamed Mahroop Raja et al. (2011), the increase of soluble solids, total sugars and reducing sugars during different stages of cauliflower development was demonstrated, the same trend was observed during storage, except for reducing sugars. Significant increase of reducing sugars, sucrose, total sugars and soluble solids was observed in both vegetables during storage. While significant increase of nitrates was obtained only in radish at the end of storage period (Table 2). This increasing pattern could be due to slower rate of hydrolysis of carbohydrates, which has implication for better quality maintenance. Radzevičius et al. (2016) found that the highest values of dry matter and soluble solids were in fully ripe ( $6^{\text {th }}$ ripeness stage) tomato fruits. Thus, crop maturity, metabolism, storage temperature and other factors, like water status (data not shown) tend to have direct and often significant and immediate impacts on total soluble solids levels of vegetable.

Table 2. Biochemical parameters of white head cabbage and radish (fresh weight, FW) during storage

\begin{tabular}{|c|c|c|c|c|c|}
\hline Organogenesis stage & $\begin{array}{l}\text { Reducing sugars } \\
\qquad{\mathrm{g} 100 \mathrm{~g}^{-1}}\end{array}$ & 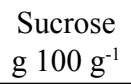 & $\begin{array}{l}\text { Total sugars } \\
\text { g } 100 \mathrm{~g}^{-1}\end{array}$ & $\begin{array}{c}\text { Soluble solids } \\
{ }^{\circ} \text { Brix }\end{array}$ & $\begin{array}{l}\text { Nitrates } \\
\mathrm{mg} \mathrm{kg}^{-1}\end{array}$ \\
\hline \multicolumn{6}{|c|}{ White head cabbage } \\
\hline II & $5.58^{*}$ & $0.26^{*}$ & $5.83^{*}$ & $7.91 *$ & 584.10 \\
\hline III & $5.60 *$ & $0.38^{*}$ & $5.98 *$ & 8.60 & 601.60 \\
\hline IV & $6.62 *$ & $0.92 *$ & $7.55^{*}$ & $9.29 *$ & 591.53 \\
\hline $\mathrm{LSD}_{0.05}$ & 0.149 & 0.132 & 0.109 & 0.329 & 10.418 \\
\hline \multicolumn{6}{|c|}{ Radish } \\
\hline II & $4.78^{*}$ & $1.49^{*}$ & $6.26^{*}$ & $9.55^{*}$ & 894.07 \\
\hline III & $8.75^{*}$ & $3.10^{*}$ & $11.86^{*}$ & $16.10^{*}$ & $830.60 *$ \\
\hline IV & $10.15^{*}$ & $3.34 *$ & $13.48^{*}$ & $19.67 *$ & $926.00 *$ \\
\hline $\mathrm{LSD}_{0.05}$ & 0.272 & 0.063 & 0.305 & 0.846 & 11.842 \\
\hline
\end{tabular}

Note. ${ }^{*}-P<0.05$ shows significant differences from trial mean using Fisher's LSD test; $\mathrm{n}=5$ plants.

Shelf life of harvested vegetables strongly depends on sugar levels (Buchanan-Wollaston et al., 2003). On the other hand, in sugar metabolism, sucrose is the main form of sugar transported to the sink tissues (Nishikawa et al., 2005). Significant decline of hexoses and sucrose in storage organs of both harvested vegetables was observed during storage (Table 3 ). Similar degradation of sucrose was observed in soybean (Sitthiwong et al., 2007) and lettuce (Suthumchai et al., 2007), besides enzymatic activity increased throughout the storage period, thus it was possible that sucrose was cleaved into uridine diphosphate glucose (UDP)-glucose and fructose.

The flowering time pathways in biannual plants are complex. It is supposed that vernalization in some cases does not create an inductive signal for development of apical meristems. Rather, it results in the removal of a block to flowering that must be overcome so that inductive signals can cause flowering in plants that are suitably competent to undergo the floral transition (Colasanti, Coneva, 2009). Moreover, most plants have autonomous flowering pathway because flowering usually occurs even in the absence of inductive environmental signals (Amasino, Michaels, 2010). Gibberellins, sucrose and glucose appears to play a major role in the floral transition, and it has been suggested that these molecules act as long-distance signalling molecules (León, Sheen, 2003; King et al., 2006; Tognetti et al., 2013). The participation of sucrose in flower evocation was shown in many plant species (Bernier et al., 1993) as well as in Brassica plants (Friend et al., 1984). In agreement with previous statements, the increasing pattern of hexoses, especially glucose, and sucrose during flower evocation (III and IV organogenesis stages) was observed in 
Table 3. The changes of soluble sugars $\left(\mathrm{mg} \mathrm{g}^{-1} \mathrm{FW}\right)$ during different stages of development

\begin{tabular}{|c|c|c|c|c|c|c|}
\hline \multirow{3}{*}{$\begin{array}{c}\text { Organogenesis } \\
\text { stage }\end{array}$} & Fructose & Glucose & Sucrose & Fructose & Glucose & Sucrose \\
\hline & \multicolumn{6}{|c|}{ White head cabbage } \\
\hline & \multicolumn{3}{|c|}{ apical meristems } & \multicolumn{3}{|c|}{ stem } \\
\hline II & $0.74^{*}$ & $0.11 *$ & $0.63^{*}$ & $0.43 *$ & 0.05 & $2.30 *$ \\
\hline III & $1.82 *$ & $0.24 *$ & $0.83^{*}$ & $0.47 *$ & 0.06 & $3.18^{*}$ \\
\hline IV & $1.46^{*}$ & $0.44^{*}$ & $2.73 *$ & $0.59 *$ & 0.04 & $2.68 *$ \\
\hline $\mathrm{V}$ & $0.43^{*}$ & $0.17^{*}$ & $0.08 *$ & $0.30 *$ & 0.05 & $1.63 *$ \\
\hline VI-VII & $0.41 *$ & $0.19 *$ & $0.00^{*}$ & $0.35 *$ & 0.03 & $1.07 *$ \\
\hline \multirow[t]{3}{*}{$\mathrm{LSD}_{0.05}$} & 0.03 & 0.01 & 0.01 & 0.02 & 0.01 & 0.03 \\
\hline & \multicolumn{6}{|c|}{ Radish } \\
\hline & \multicolumn{3}{|c|}{ apical meristems } & \multicolumn{3}{|c|}{ root-crop } \\
\hline II & $0.23^{*}$ & $0.10^{*}$ & $0.03 *$ & $0.51 *$ & $0.21 *$ & $0.14^{*}$ \\
\hline III & $0.89^{*}$ & $0.31 *$ & $0.00^{*}$ & $4.85^{*}$ & $0.92 *$ & $0.28 *$ \\
\hline IV & $1.28 *$ & $0.23 *$ & $0.02 *$ & $3.38^{*}$ & $0.81 *$ & $0.15^{*}$ \\
\hline V & $0.65^{*}$ & 0.18 & $0.24 *$ & $1.27 *$ & $0.25 *$ & $0.01 *$ \\
\hline VI-VII & $0.25^{*}$ & $0.09 *$ & 0.06 & $0.19^{*}$ & $0.20^{*}$ & $0.01 *$ \\
\hline $\mathrm{LSD}_{0.05}$ & 0.05 & 0.01 & 0.01 & 0.11 & 0.02 & 0.02 \\
\hline
\end{tabular}

Note. ${ }^{*}-P<0.05$ shows significant differences from trial mean using Fisher's LSD test; $\mathrm{n}=5$ plants.

apical meristems of both plants (Table 3). Thus many developmental processes, including cell division within the apical meristems and flowering, appear to depend on sugar signalling.

The roles of gibberellins (GAs) on floral initiation are complex and it is becoming more clear that GAs are not an universal flowering stimulus, as they promote flowering in annual and biennial species but inhibit flowering in perennials (Mutasa-Göttgens, Hedden, 2009). Gibberellins are required for normal growth of almost all plant organs, promote switching from vegetative (juvenile) growth to reproductive development (not in all species) through DELLA-mediated pathways
(Davière et al., 2008). Moreover, GAs are able to interact with other phytohormones at different levels throughout development (Weiss, Ori, 2007). On the other hand, GAs signalling pathway is tightly regulated by developmental and environmental cues (Yamaguchi, 2008). A role for GAs in flower induction has been established for long day and biennial species (King et al., 2006), spinach (Talon et al., 1991) and sugar beet (Sorce et al., 2002). Slight increase of $\mathrm{GA}_{3}$ was detected in apical meristems of white head cabbage and significant increase in apical meristems of radish during II evocation stage (IV organogenesis stage) (Table 4).

Table 4. The changes of gibberellin $\left(\mathrm{GA}_{3}\right)$ and indole-3-acetic acid (IAA) $\left(\mu \mathrm{g} \mathrm{g}^{-1} \mathrm{FW}\right)$ in apical meristems during different stages of development

\begin{tabular}{ccccc}
\hline \multirow{2}{*}{ Organogenesis stage } & \multicolumn{2}{c}{ White head cabbage } & \multicolumn{2}{c}{ Radish } \\
\cline { 2 - 5 } & IAA & $\mathrm{GA}_{3}$ & IAA & $0.039^{*}$ \\
II & $0.006^{*}$ & $0.000^{*}$ & 0.121 & $0.076^{*}$ \\
III & $0.032^{*}$ & $0.000^{*}$ & 0.419 & $0.863^{*}$ \\
IV & $0.022^{*}$ & 0.042 & 0.439 & $0.522^{*}$ \\
V & $0.018^{*}$ & 0.029 & 0.595 & $0.091^{*}$ \\
VI-VII & $0.078^{*}$ & 0.063 & $1.358^{*}$ & 0.035 \\
\hline LSD $_{0.05}$ & 0.001 & 0.041 & 0.777 &
\end{tabular}

Note. ${ }^{*}-P<0.05$ shows significant differences from trial mean using Fisher's LSD test; $\mathrm{n}=5$ plants.

These results confirm that GAs act directly to induce the floral transition of the apical meristems in Brassica species, or they may also promote formation of other mobile signals. Recent studies of auxin regulation of flower development showed that critical roles in floral meristem initiation and floral organ initiation depend on AINTEGUMENTA-LIKE/PLETHORA transcription factors, moreover, AINTEGUMENTA acts downstream of auxin in regulation of organ size (Krizek, 2011). Auxin has long been postulated as a key regulator for flower development, as it plays an essential role in initiating flower primordia (Cheng, Zhao, 2007). The lowest contents of IAA were found in both white head cabbage and radish apical meristems during juvenile period. After transition to the reproductive growth, the apical meristems turned into inflorescence meristems and initiated floral meristems. The increasing pattern of IAA accumulation was observed in both vegetables during such meristematic activity (Table 4 ). Thus changes in the local auxin gradients may be essential for organogenesis. Cheng and Zhao (2007) suggested that changes of the overall auxin levels might be not due to disruption of auxin transport. Moreover, it was found that auxin biosynthesis, auxin signalling and polar auxin transport were required to terminate the meristematic activities of floral meristems in Arabidopsis.

\section{Conclusions}

1. The switching from juvenile stage to reproductive development started in November for white head cabbage and in January for radish, winter type, 
and conditioned the beginning of evocation processes. The mitotic activity of apical meristems started and the development of floral meristems was observed only in spring - IV organogenesis stage was identified. This means that processes of II evocation stage can occur during storage, at low temperature conditions and in the dark.

2 . The increasing pattern of reducing sugars, sucrose, total sugars and soluble solids could be due to slower rate of hydrolysis of carbohydrates, which has implication for better quality maintenance. Thus, crop maturity, metabolism, storage atmosphere and other factors tend to have direct and often significant and immediate impacts on total soluble solids levels of vegetable. On the other hand, significant decline of hexoses and sucrose, probably due to sugar cleavage, in storage organs of both harvested vegetables was observed during storage.

3. The increasing pattern of hexoses, especially glucose, and sucrose, giberellin ( $\left.\mathrm{GA}_{3}\right)$ and indole-3-acetic acid (IAA) during evocation (III and IV organogenesis stages) was observed in apical meristems of both plants. Thus many developmental processes, including cell division within the apical meristems and flowering, appear to depend on sugar-hormone signalling pathway.

Received 13032017

Accepted 16062017

\section{References}

1. Amasino R. M., Michaels S. D. 2010. The timing of flowering. Plant Physiology, 154: 516-520.

2. AOAC. 1990. Official methods of analysis. Herlich K. (ed.). Arlington, USA.

3. Bernier G., Havelange A., Housa C., Petitjean A., Lejeune P. 1993. Physiological signals that induce flowering. The Plant Cell, 5 (10): 1147-1155. https://doi.org/10.1105/tpc.5.10.1147

4. Biesiada A., Nawirska A., Kucharska A., Sokół-Łętowska A 2009. The effect of nitrogen fertilization methods on yield and chemical composition of pumpkin (Cucurbita maxima) fruits before and after storage. Vegetable Crops Research Bulletin, 70: 203-211. https://doi.org/10.2478/v10032-009-0020-0

5. Buchanan-Wollaston V., Simon E., Elezabeth H., Evy M., Saeid N., Tania P., David P. 2003. The molecular analysis of leaf senescence - a genomics approach. Plant Biotechnology Journal, 1: 3-22. https://doi.org/10.1046/j.1467-7652.2003.00004.x

6. Cheng Y., Zhao Y. 2007. A role for auxin in flower development. Journal of Integrative Plant Biology, 49 (1): 99-104. https://doi.org/10.1111/j.1744-7909.2006.00412.x

7. Colasanti J., Coneva V. 2009. Mechanisms of floral induction in grasses: something borrowed, something new. Plant Physiology, 149: 56-62. https://doi.org/10.1104/pp.108.130500

8. Davière J. M., de Lucas M., Prat S. 2008. Transcriptional factor interaction: a central step in DELLA function. Current Opinion in Genetics and Development, 18 (4): 296-303. https://doi.org/10.1016/j.gde.2008.05.004

9. Dhatt A. S., Mahajan B. V. C. 2007. Horticulture. Post harvest technology. Harvesting, handling and storage of horticultural crops. Punjab Horticultural Postharvest Technology Centre, Punjab Agricultural University Campus, Ludhiana, $30 \mathrm{p}$.

10. Duchovskis P. 2000. Conception of two-phase flowering induction and evocation in wintering plants. Sodininkyste ir daržininkystè, 19 (3): 3-14.
11. El-Ramady H. R., Domokos-Szabolcsy É., Abdalla N. A., Taha H. S., Fári M. 2015. Postharvest management of fruits and vegetables storage. Lichtfouse E. (ed.). Sustainable agriculture reviews. Switzerland, p. 65-152. https://doi.org/10.1007/978-3-319-09132-7 2

12. Eveland A. L., Jackson D. P. 2011. Sugars, signaling, and plant development. Journal of Experimental Botany, 63: 3367-3377. htttps://doi.org/10.1093/jxb/err379

13. Friend D. J. C., Bodson M., Bernier G. 1984. Promotion of flowering in Brassica campestris L. cv Ceres by sucrose. Plant Physiology, 75 (4): 1085-1089. https://doi.org/10.1104/pp.75.4.1085

14. Geniatakis E., Fousaki M., Chaniotakis N. A. 2003. Direct potentiometric measurement of nitrate in seeds and produce. Communications in Soil Science and Plant Analysis, 34 (3-4): 571-579. https://doi.org/10.1081/CSS-120017840

15. Kim D. H., Sung S. 2014. Genetic and epigenetic mechanisms underlying vernalization. Arabidopsis Book, 12: e0171. https://doi.org/10.1199/tab.0171

16. King R. W., Moritz T., Evans L. T., Martin J., Andersen C. H., Blundell C., Kardailsky I., Chandler P. M. 2006. Regulation of flowering in the long-day grass Lolium temulentum by gibberellins and the FLOWERING LOCUS T gene. Plant Physiology, 141 (2): 498-507. https://doi.org/10.1104/pp.106.076760

17. Kitinoja L., Kader A. A. 2002. Small-scale postharvest handling practices: a manual for horticultural crops ( $4^{\text {th }} \mathrm{ed}$.).

18. Krizek B. A. 2011. Auxin regulation of Arabidopsis flower development involves members of the AINTEGUMENTALIKE/PLETHORA (AIL/PLT) family. Journal of Experimental Botany, 62 (10): 3311-3319. https://doi.org/10.1093/jxb/err127

19. León P., Sheen J. 2003. Sugar and hormone connections. Trends in Plant Science, 8 (3): 110-116.

20. Lepse L., Viskelis P., Lepsis J., Bimsteine G. 2014. Influence of controlled atmosphere on the carrot storage quality. Acta Horticulturae, 1033: 59-64. https://doi.org/10.17660/ActaHortic.2014.1033.8

21. Mohamed Mahroop Raja M., Raja A., Mohamed Imran M., Habeeb Rahman A. 2011. Quality aspects of cauliflower during storage. International Food Research Journal, 18: 427-431.

22. Mutasa-Göttgens E., Hedden P. 2009. Gibberellin as a factor in floral regulatory networks. Journal of Experimental Botany, 60 (7): 1979-1989. https://doi.org/10.1093/jxb/erp040

23. Nishikawa F., Iwama T., Kato M., Hyodo H., Ikoma Y., Yano. M. 2005. Effect of sugar on ethylene biosynthesis and responsiveness in harvested broccoli florets. Postharvest Biology and Technology, 36 (2): 157-165. https://doi.org/10.1016/j.postharvbio.2004.12.001

24. Paliyath G., Murr D. P., Handa A. K., Lurie S. 2008. Postharvest biology and technology of fruits, vegetables, and flowers. New Delhi, India, $497 \mathrm{p}$.

25. Radzevičius A., Viškelis J., Karklelienė R., Juškevičienė D., Viškelis P. 2016. Determination of tomato quality attributes using near infrared spectroscopy and reference analysis. Zemdirbyste-Agriculture, 103 (1): 91-98. https://doi.org/10.13080/z-a.2016.103.012

26. Sams C. E., Conway W. S. 2003. Preharvest nutritional factors affecting postharvest physiology. Bartz J. A., Brecht J. K. (eds.). Postharvest physiology and pathology of vegetables (2nd ed.). New York, USA, p. 161-176.

27. Samuolienè G., Brazaitytė A., Viršilè A., Sirtautas R., Sakalauskaite J., Sakalauskienè S., Duchovskis P. 2015. Photomorphogenetic effects in different plant life forms. Acta Horticulturae, 1099: 129-135. https://doi.org/10.17660/ActaHortic.2015.1099.12

28. Samuolienė G., Ceidaitè A., Sirtautas R., Duchovskis P., Kviklys D. 2016. Effect of crop load on phytohormones, sugars, and biennial beating in apple trees. Biologia Plantarum, 60 (2): 394-400. https://doi.org/10.1007/s10535-015-0581-3 
29. Singh S. V., Verma A. K. 2012. A mathematical expression for prediction of sugar loss in fresh produce during its storage by using a respiratory model. International Journal of Engineering Research and Development, 2 (5): 60-63.

30. Sitthiwong K., Matsui T., Okuda N., Kosugi Y. 2007. Cloning and sequencing of sucrose synthase cDNA from vegetable soybean and its expression during storage at $20^{\circ} \mathrm{C}$. Biotechnology, 6 (2): 184-192.

https://doi.org/10.3923/biotech.2007.184.192

31. Sorce C., Stevanato P., Biancardi E., Lorenzi R. 2002. Physiological mechanisms of floral stem elongation (bolting) control in sugar beet (Beta vulgaris ssp. vulgaris L.). Agroindustria, 1: 87-91.

32. Suthumchai W., Matsui T., Kawada K., Kosugi Y. 2007. Sugar metabolizing enzymes activities in lettuce head during low temperature storage. Asian Journal of Plant Science, 6: 568-576.

https://doi.org/10.3923/ajps.2007.568.576

33. Talon M., Zeevaart J. A., Gage D. A. 1991. Identification of gibberellins in spinach and effects of light or darkness on their levels. Plant Physiology, 97: 1521-1526.

https://doi.org/10.1104/pp.97.4.1521
34. Tognetti J. A., Pontis H. G., Martínez-Noël G. M. A. 2013. Sucrose signaling in plants. Plants Signaling and Behaviour, 8: e23316-1-10.

35. Vitti A., Nuzzaci M., Scopa A., Tataranni G., Remans T., Vangronsveld J., Sofo A. 2013. Auxin and cytokinin metabolism and root morphological modifications in Arabidopsis thaliana seedlings infected with cucumber mosaic virus (CMV) or exposed to cadmium. International Journal of Molecular Science, 14 (4): 6889-6902. https://doi.org/10.3390/ijms14046889

36. Weiss D., Ori N. 2007. Mechanisms of cross talk between gibberellin and other hormones. Plant Physiology, 144: 1240-1246. https://doi.org/10.1104/pp.107.100370

37. Wilkie J. D., Sedgley M., Olesen T. 2008. Regulation of floral initiation in horticultural trees. Journal of Experimental Botany, 59 (12): 3215-3228.

38. Yamaguchi S. 2008. Gibberellin metabolism and its regulation. Annual Review of Plant Biology, 59: 225-251. https://doi.org/10.1146/annurev.arplant.59.032607.092804

39. Куперман Ф. М., Ржанова Е. И., Мурашев В. В., ЛьвоваИ.Н., Седова Е. А., Ахундова В. А., Щербина И. П. 1982. Биология развития культурных растений. Москва, Россия (in Russian).

\title{
Baltagūžio kopūsto (Brassicaoleracea L.) ir valgomojo ridiko (Raphanus sativus L.) kokybès ir vystymosi kitimai pasodų saugojimo metu
}

\author{
A.Viškelienè ${ }^{1}$, G. Samuolienè $\dot{e}^{1,2}$, R. Karklelienè ${ }^{1}$, P. Viškelis ${ }^{1}$, A. Sasnauskas ${ }^{1}$, P. Duchovskis ${ }^{1,2}$ \\ ${ }^{1}$ Lietuvos agrarinių ir miškų mokslų centro Sodininkystès ir daržininkystès institutas \\ ${ }^{2}$ Aleksandro Stulginskio universitetas
}

\section{Santrauka}

Tyrimo tikslas - nustatyti Brassicaceae šeimos augalų: baltagūžio kopūsto (B. oleracea L., 'Rocktor' H) bei žieminio valgomojo ridiko (Raphanus sativus L., 'Murzynka') kokybinių rodiklių kitimus ir įvertinti fitohormonų bei tirpių angliavandenių veiklą vykstant vystymosi procesams pasodų saugojimo metu. Augalai auginti pagal skirtingas daržovių auginimo technologijas (tradicinę ir ekologinę). Ridikų ir kopūstų derlius nuimtas atitinkamai rugsẻjo 19 ir spalio 14 dienomis. Pasodai saugoti $1-4^{\circ} \mathrm{C}$ temperatūroje, esant $90 \%$ drègniui. Kopūstų ir ridikų perèjimas iš juvenalinio periodo (II organogenezès tarpsnis) ị generatyvinị vystymąsi (III organogenezès tarpsnis) prasidèjo atitinkamai lapkričio ir sausio mėnesiais; tai lèmè evokacijos procesų pradžią. Apikalinių meristemų mitotinis aktyvumas ir prefloralinių meristemų vystymasis pastebėtas tik pavasarị - nustatytas IV organogenezės etapas. Tai reiškia, kad II evokacijos etapo procesai gali prasidèti pasodų saugojimo metu, esant žemai temperatūrai ir tamsoje. Nustatyta didejjanti invertuoto cukraus, sacharozès, suminio cukraus ir tirpių sausujų medžiagų kiekio tendencija saugojimo metu galèjo būti dèl lètesnio angliavandenių hidrolizès greičio, o tai sąlygoja geresnę daržovių kokybę. Tačiau saugojimo metu abiejų daržovių sandèliniuose organuose (ridikų šakniavaisiuose ir kopūstų stiebuose) nustatytas reikšmingas heksozių (apie 1,5 ir 4,7 karto kopūstuose ir ridikuose) ir sacharozės (apie 2,0 ir 19,0 kartų kopūstuose ir ridikuose) mažejimas, tikriausiai dèl cukrų skaidymo. Evokacijos procesų metu (organogenezės III ir IV etapuose) tirtų daržovių apikalinėse meristemose nustatyta didejjanti heksozių, ypač gliukozės (2,2 karto abiejuose augaluose), sacharozès (7,5 karto kopūstuose), giberelo rūgšties $\left(\mathrm{GR}_{3}\right)$ (1,3 ir 2,2 karto kopūstuose ir ridikuose) ir auksino (IAR) (0,8 karto kopūstuose) kiekio tendencija. Taigi daugelis vystymosi procesų, taip pat ir ląstelių dalijimasis apikalinėse meristemose, žydejjimas, galimai priklauso nuo cukrų ir hormonų signalo perdavimo kelio.

Reikšminiai žodžiai: cukrūs, evokacija, fitohormonai, pasodų saugojimas, žydejjimo iniciacija. 